Boise State University

ScholarWorks

Educational Technology Faculty Publications and

Presentations

Department of Educational Technology

5-1-2017

Persistence Factors Revealed: Students' Reflections on Completing a Fully Online Program

Dazhi Yang

Boise State University

Sally Baldwin

Boise State University

Chareen Snelson

Boise State University 
This is an author-produced, peer-reviewed version of this article. The final, definitive version of this document can be found online at Distance

Education, published by Routledge. Copyright restrictions may apply. doi: 10.1080/01587919.2017.1299561

\title{
Persistence Factors Revealed: Students’ Reflections on Completing a Fully Online Program
}

\author{
Dazhi Yang \\ Boise State University \\ Sally Baldwin \\ Boise State University \\ Chareen Snelson \\ Boise State University
}

\begin{abstract}
Despite the rapid growth in online programs, online programs routinely face student attrition. How to retain students and help students successfully complete an online program is usually a top priority for online programs. This study investigated persistence factors that contributed to students' successful completion from one of the largest and most successful online programs in the United States. Results show that both personal and program attributes contributed to students' successful completion of a fully online program. Main individual attributes include interest in or career goals related to technology, time and effort invested, and perceived utility of learning. Main program attributes include relevancy of courses to individual or professional needs, satisfaction with courses and program, and ties between coursework and job promotion. Results of this study have implications for online programs in terms of prioritizing different attributes and strategizing resources to improve completion and graduation rates for fully online programs.
\end{abstract}

Keywords: persistence, online programs completion, student attrition, student retention, online program management

\section{Introduction}

Low student retention remains a major challenge in online courses and or programs despite rapid growth in online delivery (Chiyaka, Sithole, Manyanga, McCarthy, \& Bucklein, 2016). Dropping out from online courses and online programs is a consistent and prevalent issue in online learning (Hart, 2012; Park \& Choi, 2009). Negative factors such as stress and poor technical skills are cited for low retention and completion rates in online courses in some studies (Chyung, Winiecki, \& Fenner, 2004). Individual characteristics or factors that can be used to predict the persistence of online students are the focus of other studies (Bunn, 2004; Harrell \& Bower, 2011). Most studies regarding attrition in online learning were situated in online courses (Park \& Choi, 2009; Sansone, Fraughton, Zachary, Butner, \& Heiner, 2011).

The current study investigated the positive factors that prevented students from leaving or withdrawing from a fully online master's program. The study was situated in one of the largest online graduate programs in the United States. It had the students' whole journey throughout their master's program as the backdrop, which allowed researchers to track persistence factors that positively attributed to students' success in completing their program of study. In the context of online learning, persistence means an online student successfully finished all course requirements and continued on to program completion (Hart, 2012).

\section{Literature Review}

Online students typically tend to live off campus and work full time (Bocchi, Eastman, \& Swift, 2004). Most online students seeking graduate degrees are part-time students (Ivankova \& Stick, 2007). Although online students are drawn to online programs for their flexibility and convenience (Bocchi et al., 2004), a variety of personal and program or 
This is an author-produced, peer-reviewed version of this article. The final, definitive version of this document can be found online at Distance Education, published by Routledge. Copyright restrictions may apply. doi: 10.1080/01587919.2017.1299561

institutional factors that impact students' persistence in online learning. In this study, personal factors, such as students' time management skills, are factors that closely relate to each individual student and tend to be unique depending on each student's family and professional status. For example, students married with young children would normally need to devote more time to their family than students who are single or married without children. Similarly, some students' job is more time- demanding such as being a forest fire fighter in the summer. Program or institutional factors, such as technical support for online courses, are factors that relate closely to each online program and are normally beyond the control of online students.

\section{Program Factors}

First, the quality of an online program seems to be an important factor that impacts students' persistence (Meyer, Bruwelheide, \& Poulin, 2009). The quality of an online program, which reflects the quality of instructors and coursework, is undoubtedly important for persistence in online programs. Students stay enrolled largely because of "qualities of the faculty, the quality of the coursework" (Meyer et al., 2009, p. 138). In online programs, the quality of coursework lies largely in the quality and frequency of instructors' feedback. Therefore, the quality of faculty and the quality of coursework in online programs are very much intertwined. Both Baker (2010) and Hart (2012) found that quality feedback from instructors was an important persistence factor in online programs. Positive and in-time feedback not only helps students learn but also gives students a feeling of confidence (Bunn, 2004).

Another important program or institutional factor impacts students' persistence in online programs is the degree of learning students perceive in an online program (Lim \& Kim, 2003). Although some researchers argue that perceived learning does not necessarily reflect the actual learning occurred (Yang, Richardson, French \& Lehman, 2011), nonetheless, students perceived learning closely relates to students' satisfaction with online courses (Eom, Wen, \& Ashill, 2006). The above findings may explain why students' perceived learning is an important persistence factor in online programs. Additionally, the relevancy of the program or course to students' goals is also an important factor impacting motivation and persistence in online learning (e.g., Bannier, 2010; Kim \& Frick, 2011). Students feel more motivated to learn and are more likely to stay when they see value in their education (Müller, 2008), which ties back to the quality of online faculty and coursework. This also reflects another aspect of the quality of an online program that offers valuable learning and adequate challenges for its students.

Institutional support is important, too (Kim \& Frick, 2011). Students must receive support for technical difficulties and have access to institutional resources, like the library, in order to perform in their courses. For online programs to succeed, online programs need to exercise sound management in order to provide adequate student support and maintain the program quality, which has everything to do with the retention and completion rate of online courses and programs. With the backdrop of more and more higher education institutions considering online learning as part of their strategic growth (Allen \& Seaman, 2016), administrators of online programs have more say and power in terms of their influence on online programs and students' retention. For example, administrators can decide about the institutional support, which impacts students' completion rate in online programs (Lee \& Choi, 2011). Administrators can decide whether and how after-hours technical support and university owned software and tools are freely available for both students and instructors. In addition, since online learning changes constantly due to the advances of educational technologies and research (Chiyaka et al., 2016), online programs need to frequently evaluate their faculty, courses, and programs to keep their competitive edge and be ready to face new challenges. This kind of ongoing evaluation and assessment is part of an institutional support and practice that impacts both the quality of online courses and the quality of online instructors.

Furthermore, online admissions staff who consist of institutional support usually are the first people potential students will be in contact with, and walk students through the admission and screening process (Farrell, 2009). The admission and admission screening staff could be a key resource that impacts every single student's academic stay in an online program. If initial rapport between admission staff and the students has been established, and periodic check-ins are maintained during a student's stay, online students would reconsider leaving the program even if they have to.

Last but not the least, it is important for online instructors and program administrators to be knowledgeable of current online learning literature and practice in terms of factors impacting students' retention and completion in order to make well-informed decisions (Bawa, 2016). Therefore, it is necessary for instructors and administrators to work closely with practitioners and researchers to achieve successful student retention. For example, some online programs have monetary incentives for updating and revising online courses, and for adopting emerging technologies based on 
This is an author-produced, peer-reviewed version of this article. The final, definitive version of this document can be found online at Distance Education, published by Routledge. Copyright restrictions may apply. doi: 10.1080/01587919.2017.1299561

latest research findings. The above mentioned aspect could also be an influencing program or institutional factor that impacts the quality of an online program, therefore impacting students' persistence in the online program.

\section{Personal Factors}

Main personal factors that impact students' persistence in online courses include: satisfaction with online courses or sense of accomplishment, personal goals, a sense of community and belonging, family support, and time management skills (Hart, 2012).

Students’ satisfaction with online courses is an important persistence factor (Lim \& Kim, 2003). Students' satisfaction with an online course and instructor positively correlates with students' perceived learning in online courses (Ferguson \& DeFelice, 2010). Eom, Wen, and Ashill (2006) indicate that user satisfaction is a significant predictor of learning outcomes. These results suggest a two-way causal effect; students are more satisfied when they perceive they are learning, and are more likely to learn when they are satisfied with their learning outcomes, which both contribute to students' persistence in online programs.

Students may choose an online program because it is a good fit with personal or professional goals (Bannier, 2010; Sansone et al., 2011). Students need to feel that the program they choose to study fits with and supports their personal and professional growth (Müller, 2008). Students feel more motivated to learn and are more likely to persist when they have an interest in the content (Baker, 2010). Chances are if a program fits with a student's personal or professional goals, a student would be more interested in the program and consequently would be more likely to persist in the program.

A sense of community and belonging in an online program helps students overcome the feeling of isolation and being overwhelmed due to a lack of face-to-face interaction in online courses (Hawkins, Barbour, \& Graham, 2012). Willging and Johnson (2009) pointed out that a lack of a sense of community and belonging in online programs increased the possibility of students' dropping out as well as poor academic performance. With the lack of face-toface interaction, online students have a need for social connectedness. When students feel connected to instructors, classmates, and the program, their experience is more positive, which helps them stay in the program (Baker, 2010; Johnston, Killion, \& Oomen, 2005).

It is obvious that convenience and high quality online programs attract students and help prevent them from dropping out. However, the students' ability to persist in online programs is also impacted by the students' ability to pay for the program and have adequate support from family, friends and work (such as child care and flexible work schedule) (Ivankova \& Stick, 2007; Rovai, 2003). Support from family and work also greatly improves online students time management, which is critical for completing the necessary coursework.

Time management skills is also an important factor that impacts students' persistence in online programs. The flexibility and convenience of online programs help students persist while balancing work and family (Müller, 2008). However, to persist in an online program, students need good time management skills to balance their coursework, job responsibilities and family. On one hand, Katiso (2015) found a statistically significant relationship existed between online students' time management skills and their motivation level toward their academic goals, which means that time management skills can contribute to students' persistence in an online program. On the other hand, students who are enrolled in more online courses are more likely to persist (Aragon \& Johnson, 2008), which in a way could demonstrate that time management skills facilitate students' completion of an online program. The above findings align with research that has found students committed to a goal are most likely to persist (Ivankova \& Stick, 2007), in that the more courses a student completes, the closer a student will be to completion (i.e., his/her goal).

Many studies have examined various factors impacting students' persistence in online programs. Some factors are personal and others are program-related. Most studies on persistence in online learning were situated within individual online courses (Baker, 2010; Sansone et al., 2011). Few studies that have looked at student persistence were situated in online programs or examined persistence in students who have completed an online program. These few studies have either focused on individual factors such as students' characteristics (Bocchi et al., 2004; Harrell \& Bower, 2011) or focused on factors that can predict persistence in online learning (Holder, 2007; Harrell \& Bower, 2011). The current study was situated within a fully online master's program and examined students' actual completed journey, focusing on persistence not prediction factors via students' reflections. 
This is an author-produced, peer-reviewed version of this article. The final, definitive version of this document can be found online at Distance Education, published by Routledge. Copyright restrictions may apply. doi: 10.1080/01587919.2017.1299561

This study builds on prior research, while acknowledging the complexity of identifying factors surrounding student persistence in online program. This complexity was noted by Hart (2012) who conducted a comprehensive review of the literature on student persistence in online education. The results of the review suggest that overall satisfaction with online learning, a sense of belonging, motivation, support, time management skills, and good communication are important factors. Yet, there remains a lack of consensus on factors of student persistence in online programs. Factors can emerge from the students themselves (individual attributes) or the program they belong to (institutional attributes). The present study adds to the literature by examining these factors in students who have successfully completed an online program.

The research question was: Why were some students able to complete and graduate from a fully online master's program? Or, more specifically, what persistence and motivational factors contributed to students' successful completion of a fully online master's degree? By answering this question, the researchers were hoping to identify factors that could improve completion and graduation rates for fully online programs, and help identify at-risk students in online courses and programs.

\section{Method}

\section{Context of Study and Participants}

The study was situated in the Department of Educational Technology (EdTech) at a U.S. urban university. The EdTech Department has one doctorate (Ed.D. program created in 2013), two master's degrees, three graduate certificates, and a K-12 online teaching endorsement program, which are all fully online. The department has 16 full-time faculty members and also employs several adjunct faculty members on a long-term basis. At least five djunct faculty members have been teaching for the EdTech Department for more than five years. Despite facing strong competition from other similar online programs nation-wide, the EdTech Department currently has more than 400 graduate students enrolled. The EdTech online programs consistently remain among the largest and most successful online programs in the United States (NCES, 2014). All the courses in the EdTech Department are taught completely online without any face-toface meetings. All classes are typically hosted in Moodle (an online course management system like Blackboard). A variety of synchronous and asynchronous communication tools (e.g., blogs, wikis, desktop video conferencing) are integrated to support the overall learning experience.

The EdTech graduate students were primarily practicing teachers in K-20 institutions or those who interacted with teachers in some capacity such as technology coordinators or specialists. The Master of Education Technology (MET) candidates were required to take a portfolio class after completing all necessary course work for their Master's degree. In the portfolio class, students produced an eportfolio with four required elements:

1. A collection of artifacts (i.e., projects, papers, and other relevant examples of work) completed during the MET study and mapped to the Association for Educational Communication and Technology (AECT) standards (2001) (http://www.aect.org/standards/initstand.html).

2. A rationale paper describing the selected artifacts and how they demonstrate the mastery of the AECT standards.

3. A reflection video telling the story of professional growth attained during the master's program.

4. An eportfolio website with links to the above three elements.

Although the reflection video was a course requirement, students were candid and spoke openly about their experience. The students talked more casually than expected. Almost every student started his or her video talking about why he or she began the program, and what helped them complete the program, even though this was not a required element of the video. Two of the three authors have taught the eportfolio course and have been reviewing the students' portfolios for several years and considered the videos a genuine and valid source for persistence factors based on their teaching and experience in reviewing reflection videos.

This study analyzed 52 participants' reflection videos for persistence factors and reported the findings. Participants for the data analysis were selected from appropriately 500 MET graduates from spring 2010 to spring 2014. Purposeful sampling was adopted in order to select information-rich participants from a wide range of variations in participants' employment type and level (Patton, 2002). It was "information-rich" in the sense of that participants had the 
This is an author-produced, peer-reviewed version of this article. The final, definitive version of this document can be found online at Distance Education, published by Routledge. Copyright restrictions may apply. doi: 10.1080/01587919.2017.1299561

opportunity to reflect on their learning experience in the videos while fresh within their memories. Almost all of the MET students in the online program were employed full-time or part-time. Participants were selected with the aim to include as much variety as possible in terms of employment type (e.g., teacher and instructional designer) and grade level (e.g., K-6, middle or high school). Table 1 lists the participants’ background information.

[Insert Table 1 here]

During the course of the portfolio class, as part of the course requirement, all graduates' videos were posted publicly online so that they could be reviewed by their peers as well as evaluated and graded by two faculty members from the graduates' program. Some students took down their eportfolio website including the link to the reflection video after the graduation. The selection of the videos (participants) was also based on whether the videos were publically accessible at the time of the study. The researchers submitted an IRB protocol and asked for the waiver of the informed participants' consent for analyzing the videos because all videos were public and it was not applicable to contact the students for consent since all students had graduated and left the program. Data analysis started after the approval of the IRB protocol.

\section{$\underline{\text { Data Analysis }}$}

The selected 52 reflection videos were reviewed and pertinent statements were transcribed into texts for analysis. A grounded theory approach was adopted in analyzing the video transcripts to find salient factors that impacted students' persistence and motivation in completing the online program (Pandit, 1996). However, before we started to analyze the videos transcripts, we previewed all the videos to get a sense of what the videos were about in terms of coding. Based on the faculty researcher's years of teaching the eportfolio course, the influencing factors indicated in the literature review, and the preview of all the reflection videos, the researchers developed an initial coding scheme. The initial coding scheme served as a loose framework for categorizing the revealed salient factors and it did not constrain the coding. For example, in the literature, the "family support" seems to be an influencing factor for students' persistence, which did not reveal much in our coding. Similarly, "able to transfer learning" was a new category emerged from our coding texts related to using educational technology skills and knowledge in other disciplines such as improving teaching sign language. We later merged "able to transfer learning" into the program factor category of "Satisfaction with Courses, Program, and Learning Outcomes" (see Table 2) considering educational technology is by large an interdisciplinary field.

A graduate researcher manually coded all transcripts and categorized the coding. A faculty member reviewed all coding and the transcripts. The faculty member and the graduate researcher discussed the differences regarding coding the same or similar statements. The faculty member also made some coding corrections after referring back to the reflection videos. After all differences were resolved, different categories of codes were exported into Excel for descriptive statistics analysis. During the process of coding and resolving the differences, we felt that the "attribute" would be more accurate than "factor" because the identified factors were closely associated with the students and the program.

\section{Results}

Based on an analysis of the 52 MET students' reflection videos, a combination of individual and program attributes influenced students' persistence in their online graduate program studies. All participants $(\mathrm{N}=52)$ indicated at least three persistence attributes that contributed to their successful completion of the online program. All participants $(\mathrm{N}=52)$ attributed both individual and program attributes to their success. Table 2 indicates the individual and program attributes, and the percentage of participants who cited each attribute. We reported the attributes that indicated by at least one thirds of the participants since we were interested in salient attributes contributing to students' completion of a fully online program.

[Insert Table 2 here]

The following results offer excerpts of the participants' paths through the program, highlighting the most important persistence attributes of their journey based on the frequency which attributes were mentioned. 
This is an author-produced, peer-reviewed version of this article. The final, definitive version of this document can be found online at Distance

Education, published by Routledge. Copyright restrictions may apply. doi: 10.1080/01587919.2017.1299561

\section{$\underline{\text { Individual Attributes }}$}

In regards to individual attributes, all of the participants claimed at least one of the six individual attributes (see Table 2) contributed to their successful completion of the online MET program. Most participants $(n=39)$ noted a sense of accomplishment, pride, or personal learning and growth motivated them to persist in their studies. In one video, a participant noted her excitement of showing all of the hard work she had done throughout the program. Another participant reported the many changes that had surfaced in her teaching, as a result of the program, noting a sense of accomplishment and personal growth. The participant indicated,

Since becoming a student of educational technology, I've noticed a change in my behavior at work, I'm more apt to take initiative and introduce new ideas and suggestions for instructional initiatives. I also am more comfortable taking on leadership roles at work because I have become more confident in my knowledge, skills and abilities, especially those related to instructional design and technology use in the classroom.

The mastery of different skills, that is gaining knowledge/skills of using specific tools (e.g. Camtasia, Audacity, etc.) was also described by most of the participants $(n=39)$, as a factor of their persistence. For example, one participant stated,

These courses introduced me to web conferencing software like Adobe Connect. I learned how to use the software for both asynchronous and synchronous lessons and learned the importance of interacting with participants in synchronous environments. In addition,... I learned about using Wikis for collaborative activities, developing rubrics to assess online instruction and the importance of building a community with online instruction.

Another participant also stated the mastery of similar skills,

In addition to learning management systems such as Blackboard, Moodle, and Web CT, I was very pleased to have a hands-on how-to design lesson evaluation tool incorporating activities such as wikis, blogs, in the future open software such as Google Applications.

Aligned with the mastery of specific skills are the next most frequently cited attribute, perceived utility of learning (i.e., the ability to transfer learning to other occasions) $(n=36)$. A participant explained,

The master [Master's] in educational technology program has empowered me to use the skills that I have gained throughout my course programs, incorporate my newfound skills in a corporate environment and set a higher degree and achievable standard, not only for myself but for others as well.

Another participant noted, "The website that I built to supplement my face-to-face business studies course is a culmination of the knowledge I acquired in my [educational technology MET] courses."

Participants also reported that the program had helped them in succeeding in their current field (i.e., having met their career goals) (n=36). For example, one participant stated, "I wanted to design training materials that would allow corporate employees to easily understand their job requirements and to also have the capability to integrate visual literacy for the disabled minorities in the workforce....”. Some participants also expressed an interest in exploring new opportunities related to the online program. For example, one participant stated, "I wanted to continue in the field of education, [but] without being limited to a career as a classroom teacher. [My graduate studies would open up more opportunities]." Overall, the pursue of the Master's degree helped the majority of participants accomplish or explore their professional or personal goals.

Another salient individual attribute frequently identified by the participants was the candidate's interest in technology or in a technology-related career $(\mathrm{n}=30)$. One participant stated, "I wanted to incorporate [my interest in technology and teaching technology] to expand my teaching area.” Another participant mentioned,

I have worked in the public and private sector serving a number of roles from either doing documentation, conducting training for users or departments, doing programming, or working on hardware and software issues. And I was looking for something to complement my career and add on to my current experience. 
This is an author-produced, peer-reviewed version of this article. The final, definitive version of this document can be found online at Distance

Education, published by Routledge. Copyright restrictions may apply. doi: 10.1080/01587919.2017.1299561

An additional individual attribute cited by some participants ( $\mathrm{n}=19)$, was the high degree of time and effort they had invested in the program. A participant stated, "The last two years have been great. It has been challenging, it's been difficult. At times I felt like my brain was going to explode but I’ve finally come to the end of the road.”

Interestingly, it seemed that candidates' technical skill or ability did not appear to be a key factor that influenced participant persistence in online programs. Only eight out of the 52 participants considered being adept at technology helped them stay and complete their master’s program.

\section{Program Attributes}

Program attributes, which we refer to features of the collection of courses and beyond, were also cited in the participants' videos. The relevancy of program to individual/professional needs was identified as the most important program attribute $(\mathrm{n}=51)$ that contributed to student persistence. Please be aware the difference between having met career goals (personal attribute) and the relevancy of program to individual/professional needs (program attribute). The former is more broad and abstract and the later relates to specific job responsibility and tasks.

For the relevancy of the program to individual/professional needs, which enhanced the ability of participants to apply learning to professional life; one participant reported, "this program has prepared me to be a highly effective teacher both in my content area and as an educational technologist." Another participant stated, "This program has helped me grow professionally and change the trajectory of my professional life." Another participant indicated, "all the classes have had so many opportunities for me to customize the assignments, to make them [classes] relevant to what I do, every day."

The participants' satisfaction with courses, program, and learning outcomes (satisfaction as a result of a part of educational experience) was also frequently mentioned $(n=47)$ in the videos. One participant reflected,

I've really enjoyed the program, I learned a whole lot of information that I just don't think I'd be able to go on in my job without at some point. So I have the greatest regard for the program....

Another participant declared,

This program has given me in-depth knowledge in both learning theories and technical skills. I now know not only how to create and deliver an effective lesson but also I understand how to apply theory to the lesson I built.

Participants were also satisfied with the combination and sequence of courses, as one participant explained, "All five of the classes ...helped lay the foundation for my EdTech degree and have provided me with skills I know I will use in the future." Participants also appreciated that the program "challenged [them] to think outside of the classroom," and a participant commented, "This program has been extremely rewarding to me over the past two years and provided my life with some focus."

Institutional support (i.e., support for program from institutional staff and faculty) was also impactful for participants $(\mathrm{n}=21)$. Most participants expressed their gratitude toward the faculty and staff's support during their journal in their video. One participant exclaimed his desire to "thank all my professors for their talents and knowledge." Others echoed the desire to "thank ... all of my instructors .... it is because of you that I have now gained advanced knowledge in educational technology.” Participants also cited the staff, for instance,

The first person I talked to was [Mr. J]. [Mr. J] was so enthusiastic. He answered all of my questions and was very encouraging that it was a great program. Throughout my two years he has been my advisor really, no offense to ....my assigned advisor, but any time I had a question or wasn’t sure which class to focus on during my electives I would call [Mr. J].

Participants ( $\mathrm{n}=19)$ also mentioned being promoted or given more responsibility as a result of their education in the online program. One participant expressed, "I'm being called on to lead more professional development workshops at my school and this project [the MET program] has given me the foundation I need to go into these experiences, prepared and competent." Another participant stated, "I've taken on a leadership role in my department and on the 
This is an author-produced, peer-reviewed version of this article. The final, definitive version of this document can be found online at Distance Education, published by Routledge. Copyright restrictions may apply. doi: 10.1080/01587919.2017.1299561

staff in my school and I've conducted several in service activities demonstrating the technology integration for staff.” And several participants boasted, "I actually got the first job I applied for because I talked about technology so much...”.

I have definitely gained tools to become a strong leader as an instructional technologist. I have been promoted chair of the Academic Technology Committee and I have also been promoted to the chair of the Faculty Development Committee. I'm constantly asked to sit in on subcommittee meetings, to give my viewpoint on technology and how it can enhance instruction.

The participants were eager to display their work during the videos and discuss the individual and program attributes that impacted their education. While a limitation of the study could be that linking these attributes to persistence and motivation in the MET program was not directly stated, the participants used the culminating video as a way to describe their path through the program, indicating the most salient details.

\section{Discussion}

We categorized the salient attributes into personal or program attributes and reported the frequencies each attribute was cited. This categorization of findings facilitates online programs' decision making in terms of choosing areas to improve while referring to the outcomes of this study. The results show that both individual and program attributes contributed to students' persistence in a fully online MET program. However, the program attributes "Relevancy of Program to Individual/Professional Needs" and "Satisfaction with Courses, Program, and Learning Outcomes” played a bigger role as more than $90 \%$ participants indicated these two positive attributes in their videos (see Table 2). Therefore, the most important factors for online programs to improve retention are to link coursework to student practice, help students acquire specific skills, and help students see the value of their learning. Making coursework relevant to students' professional practice and improving student satisfaction with courses, program, and learning outcomes are also critical for improving retention in online programs. The findings with the program attributes in this study is consistent with previous literature on the impact of quality of online course and program on students' persistence (Meyer et al., 2009).

Personal attributes were not as frequently cited as the two program attributes, the relevancy of program, and satisfaction with courses, programs and learning outcomes. However, more than two thirds of the participants indicated that "Sense of Accomplishment", "Mastery of Specific Skills", "Perceived Utility of Learning", "Meeting Career Goals" were important for their completion of the online program. Therefore, these are the four areas that online programs can tap into to improve their students' retention and completion rate.

It seems that participants' interest in technology or having a technology-related career are more important than student technology skills and ability in terms of its effect on persistence in online programs. Students' technological ability does not seem to be a persistence factor for this particular group of students. This finding is different from previous studies (Dupin-Bryant, 2004; Ivankova \& Stick, 2007) that suggested technological skills were a key factor in online students' ability to persist and keep up with coursework. This might be due to the fact that students in educational technology are generally more technologically adept. Future studies need to examine different groups of students with different levels of technology competency for persistence.

Institution support is also an important program attribute to students' persistence. In this particular study, the relationship between an online program admissions staff and the students mattered for students. This demonstrates the importance of establishing rapport between online program staff and students at the very beginning. It is also important for online programs to promote and create support networks so that students can solve some personal or professional problems, which may prevent them from dropping out of an online program.

The personal attribute "Amount of Time and Effort in Program" and program attribute "Program Tied to Job Promotion/Additional Responsibility” seem to be equally influential for students' persistence in online programs. The former was consistent with previous research in that the more time students spent on the program, the less likely they are going to withdraw from the program (Aragon \& Johnson, 2008). Therefore, online programs may want to focus on the first several courses their students normally take to keep the students staying for more courses. For the latter, online programs may want to capitalize on some factors such as publishing job announcements for their students and 
This is an author-produced, peer-reviewed version of this article. The final, definitive version of this document can be found online at Distance Education, published by Routledge. Copyright restrictions may apply. doi: 10.1080/01587919.2017.1299561

communicating the success of their students and alumni to fellow stakeholders. Within an institution, encouraging students to report victories (e.g., overcoming a challenge in course, meeting a goal, or getting a promotion), would help recognize success and encourage students to continue to persist in their studies.

\section{Conclusion}

Each dropout has individual and unique factors that influence the action of withdrawing from an online course or program (Willging \& Johnson, 2004). However, results from this study show that the persistence attributes clustered in the sense that participants had similar attributes that contributed to their completion of the fully online MET program. This supports that "If persistence factors are not present in sufficient quantity, the student may be at risk of withdrawing from an online course" (Hart, 2012, p.19).

This study focused on positive factors contributing to students' successful completion of a fully online program but it has limitations. First, the data source for the findings were the reflection videos. Although most students revealed valid factors that helped them succeed, follow-up interviews or a focus group may uncover more than what was expressed in the videos. Thus, additional methods of data collection could shed more light on this topic of study. Second, the participants of this study were unique graduate students who for the most part successfully maintained full-time employment, indicating good time management skills. Thus, the findings of this study cannot be readily generalized to other populations.

Despite the limitations, knowledge from this study could help improve online program completion and graduation rates, and identify at-risk students. Based on the findings, online programs need to consider both personal and programmatic attributes, and prioritize the factors that impact students' completion of an online program. Online programs need to strategize resources to improve completion and graduation rates. Resources spent on professional development, technical support for faculty, and paid course updates or redesign could have a positive impact on student retention rate (Chiyaka et al., 2016). Also, constant and ongoing evaluation of online teaching, teaching methods, instructors' competencies, and best practices are important to ensure high quality of online courses and programs (Meyer \& Murrell, 2014; Mujtaba, 2011). Although the complexity of identifying factors surrounding students' persistence in online program is well noted, it is safe to conclude that we can increase retention with the proper program support from course instructors as well as with personal support for students (Park \& Choi, 2009).

\section{References}

Ajjan, H., \& Hartshorne, R. (2008). Investigating faculty decisions to adopt web 2.0 technologies: Theory and empirical tests. The Internet and Higher Education, 11, 71-80. doi: 10.1016/j.iheduc.2008.05.002

Allen, I. A., \& Seaman, J. (2016). Online report card. Tracking online education in the United States. Babson Park, MA: Babson Survey Research Group.

Association for Educational Communications and Technology (AECT). (2001). What are the initial standards? Retrieved from http://www.aect.org/standards/initstand.html

Baker, C. (2010). The impact of instructor immediacy and presence for online student affective learning, cognition, and motivation. Journal of Educators Online, 7(1). Retrieved from http://files.eric.ed.gov/fulltext/EJ904072.pdf

Bannier, B. J. (2010). Motivating and assisting adult, online chemistry students: A review of the literature. Journal of Science Education and Technology, 19, 215-236.

Bawa, P. (2016). Retention in online courses: Exploring issues and solutions -A literature review. Sage Open. Retrieved from http://sgo.sagepub.com/content/spsgo/6/1/2158244015621777.full.pdf

Bocchi, J., Eastman, J. K., \& Swift, C. O. (2004). Retaining the online learner: Profile of students in an online MBA program and implications for teaching them. Journal of Education for Business, 79(4), 245-253.

Brill, J. M., \& Galloway, C. (2007). Perils and promises: University instructors’ integration of technology in classroom-based practices. British Journal of Educational Technology, 38, 95-105. doi:10.1111/j.14678535.2006.00601.x

Bunn, J. (2004). Student persistence in a LIS distance education program. Australian Academic \& Research Libraries, 35, 253-269. 
This is an author-produced, peer-reviewed version of this article. The final, definitive version of this document can be found online at Distance Education, published by Routledge. Copyright restrictions may apply. doi: 10.1080/01587919.2017.1299561

Chiyaka, E. T., Sithole, A., Manyanga, F., McCarthy, P., \& Bucklein, B. K. (2016). Institutional characteristics and student retention: What integrated postsecondary education data reveals about online learning. Online Journal of Distance Learning Administration, XIX(2). Retrieved from http://www.westga.edu/ distance/ojdla/summer192/chiyaka_sithole_manyanga_mccarth y_bucklein192.html

Chyung, Y., Winiecki, D. J., \& Fenner, J. (1998). A case study: Increase enrollment by reducing dropout rates in adult distance education. Distance Learning '98: Proceedings of the 14th Annual Conference on Distance Teaching \& Learning (pp. 97-102). Madison, WI: University of Wisconsin-Madison.

Dupin-Bryant, P. (2004). Pre-entry variables related to retention in online distance education. American Journal of Distance Education, 18, 199-206.

Eom, S. B., Wen, H. J., \& Ashill, N. (2006). The determinants of students' perceived learning outcomes and satisfaction in university online education: An empirical investigation. Journal of Innovative Education, 4, 215-235.

Farrell, P. L. (2009). Investing in staff for student retention (pp. 85-92). The NEA 2009 Almanac of High Education. Retrieved from http://www.nea.org/assets/img/PubAlmanac/ALM_09_08.pdf

Ferguson, J. M., \& DeFelice, A. E. (2010). Length of online course and student satisfaction, perceived learning, and academic performance. The International Review of Research in Open and Distributed Learning, 11, 7384.

Harrell, I. L., \& Bower, B. L. (2011). Student characteristics that predict persistence in community college online courses. American Journal of Distance Education, 25, 178- 191.

Hart, C. (2012). Factors associated with student persistence in an online program of study: A review of the literature. Journal of Interactive Online Learning, 11, 19-42.

Hawkins, A., Barbour, M. K., \& Graham, C. R. (2012). Everybody is their own island: Teacher disconnection in a virtual school. International Review of Research in Open and Distance Learning, 13(2). Retrieved from http://www.irrodl.org/index.php/irrodl/article/view/967

Holder, B. (2007). An investigation of hope, academics, environment, and motivation as predictors of persistence in higher education online programs. The Internet and Higher Education, 10, 245-260.

Ivankova, N. V., \& Stick, S. L. (2007). Students' persistence in a distributed doctoral program in educational leadership in higher education: A mixed methods study. Research in Higher Education, 48, 93-135.

Johnston, J., Killion, J., \& Oomen, J. (2005). Student satisfaction in the virtual classroom. The Internet Journal of Allied Health Sciences and Practice, 3(2), 1-7.

Kane, R. T., Shaw, M., Pang, S., Salley, W., \& Snider, J. B. (2016). Faculty professional development and student satisfaction in online higher education. Online Journal of Distance Learning Administration, 19(2), Retrieved from http://www.westga.edu/ distance/ojdla/summer192/kane_shaw_pang_salley_snider192.h tml

Kim, K. J., \& Frick, T. W. (2011). Changes in student motivation during online learning. Journal of Educational Computing Research, 44, 1-23.

Lee, Y., \& Choi, J. (2011). A review of online course dropout research: implications for practice and future research. Educational Technology Research and Development, 59, 593-618. doi: 10.1007/s11423-010-9177-y

Lim, D. H., \& Kim, H. (2003). Motivation and learner characteristics affecting online learning and learning application. Journal of Educational Technology Systems, 31(4), 423-439.

Meyer, K. A., Bruwelheide, J., \& Poulin, R. (2009). Why they stayed: Near-perfect retention in an online certification program in library media. Journal of Asynchronous Learning Networks, 13(3), 99 -115.

Meyer, K. A., \& Murrell, V. (2014). A national study of training content and activities for faculty development for online teaching. Journal of Asynchronous Learning Networks, 18(1), 3-18.

Mujtaba, B. (2011). Faculty training and development practices in distance education to achieve high performance through extraordinary teaching. Journal of College Teaching \& Learning (TLC), 1, 73-89.

Müller, T. (2008). Persistence of women in online degree-completion programs. International Review of Research in Open \& Distance Learning, 9(2). Retrieved from http://www.irrodl.org/index.php/irrodl/article/view/455/1042

National Center for Education Statistics (NCES) (2014). Integrated Postsecondary Education Data System (IPEDS). Available from http://nces.ed.gov/ipeds/

Pandit, N. R. (1996). The creation of theory: A recent application of the grounded theory method. The Qualitative Report, 2(4), 1-15.

Patton, M. Q. (2002). Qualitative research and evaluation methods (3rd ed.). Thousand Oaks, CA: Sage. 
This is an author-produced, peer-reviewed version of this article. The final, definitive version of this document can be found online at Distance Education, published by Routledge. Copyright restrictions may apply. doi: 10.1080/01587919.2017.1299561

Park, J. H., \& Choi, H. J. (2009). Factors influencing adult learners' decision to drop out or persist in online learning. Journal of Educational Technology \& Society, 12, 207-217.

Rovai, A. P. (2003). In search of higher persistence rates in distance education online programs. The Internet and Higher Education, 6, 1-16.

Sansone, C., Fraughton, T., Zachary, J. L., Butner, J., \& Heiner, C. (2011). Self-regulation of motivation when learning online: The importance of who, why and how. Educational Technology Research and Development, 59, 199-212.

Tinto, V. (2012). Completing college: Rethinking institutional action. Chicago, IL: University of Chicago Press.

Willging, P. A., \& Johnson, S. D. (2004). Factors that influence students' decision to dropout of online courses. Journal of Asynchronous Learning Networks, 8, 105-118.

Yang, D., Richardson, J. C., French, B. F., \& Lehman, J. D. (2011). The development of a content analysis model for assessing students' cognitive learning in asynchronous online discussions. Educational Technology Research and Development, 59, 43-70.

Table 1. Participants' background information

\begin{tabular}{|l|l|l|}
\hline Position & Level & Number of Participants \\
\hline Teacher & K-6 & 7 \\
\hline Teacher & Middle School & 6 \\
\hline Teacher/ Instructional Technologist & High School & 10 \\
\hline $\begin{array}{l}\text { Teacher/ Instructional Technologist/Web Designer/ } \\
\text { ESL or other kinds of Coordinator }\end{array}$ & $\begin{array}{l}\text { K-12 (participant didn't specify } \\
\text { K-6 or other levels) }\end{array}$ & 12 \\
\hline $\begin{array}{l}\text { Faculty (lecture, tenure-track or tendered } \\
\text { professor)/ Instructional Technologist }\end{array}$ & Higher Education & 7 \\
\hline $\begin{array}{l}\text { Athlete/ Education Technician/ Content Specialist// } \\
\text { Unemployed/ Designer/ Editor/ Outreach } \\
\text { Coordinator }\end{array}$ & & 10 \\
\hline
\end{tabular}

Table 2: Identified salient persistence factors

\begin{tabular}{|l|l|l|}
\hline \multicolumn{2}{|l|}{ Persistence Factors } & Percent \\
\hline $\begin{array}{l}\text { Individual } \\
\text { attributes (IA) }\end{array}$ & Candidate is Interested in Technology (IA1) & $72 \%$ \\
\cline { 2 - 3 } & Amount of Time and Effort in Program (IA2) & $41 \%$ \\
\cline { 2 - 3 } & Mastery of Specific Skills (IA3) & $86 \%$ \\
\cline { 2 - 3 } & Perceived Utility of Learning (IA4) & $79 \%$ \\
\cline { 2 - 3 } & Career Goals (IA5) & $72 \%$ \\
\cline { 2 - 3 } & Sense of Accomplishment (IA6) & $72 \%$ \\
\hline $\begin{array}{l}\text { Program } \\
\text { attributes (PA) }\end{array}$ & Satisfaction with Courses, Program, and Learning Outcomes (PA1) & $93 \%$ \\
\cline { 2 - 3 } & Institutional Support (PA2) & $38 \%$ \\
\cline { 2 - 3 } & Relevancy of Program to Individual/Professional Needs (PA3) & $93 \%$ \\
\cline { 2 - 3 } & Program Tied to Job Promotion/Additional Responsibility (PA4) & $45 \%$ \\
\hline
\end{tabular}

